\title{
PERLUASAN PENGATURAN PENGURUSAN PERSEROAN TERBATAS DALAM PEMBAHARUAN HUKUM PERSEROAN TERBATAS
}

\author{
Pande Putu Indahyani Lestari, Fakultas Hukum Universitas Udayana, e-mail: \\ putuindah2599@gmail.com \\ I Gede Agus Kurniawan, Univesitas Pendidikan Nasional, e-mail: \\ gedeaguskurniawan@undiknas.ac.id
}

doi: https://doi.org/10.24843/KS.2020.v08.i10.p01

\begin{abstract}
ABSTRAK
Tujuan studi ini untuk mengkaji perluasan pengaturan pengurusan perseroan terbatas dalam pembaharuan hukum Perseroan Terbatas. Dalam UUPT menyebutkan bahwa Direksi berwenang dan bertanggung jawab penuh untuk menjalankan pengurusan Perseroan. Studi ini menggunakan metode penelitian hukum normatif, yakni suatu penelitian menggunakan berdasarkan dengan pendekatan bahan hukum, baik hukum primer dan hukum sekunder. Hasil studi menunjukkan bahwa Direksi sebagai organ perseroan bertanggung jawab atas kepentingan Perseroan, apabila dalam suatu Perseroan tidak memiliki Direksi maka Perseroan tidak akan bisa berjalan atau beroperasional dengan baik selayaknya sebuah badan hukum. Kemudian dalam hal ini ketika masa jabatan Direksi sudah habis mengakibatkan terjadinya kekosongan kepengurusan Direksi, di dalam UUPT tidak ada yang mengatur manakala suatu Perseroan sudah tidak memiliki Direksi.
\end{abstract}

Kata Kunci: Perseroan Terbatas, Direksi, Tanggung Jawab

\begin{abstract}
The purpose of this study is to examine the expansion of management arrangements for limited liability companies in the legal renewal of Limited Liability Companies. The UUPT states that the Directors are authorized and fully responsible for carrying out the management of the Company. This study uses a normative legal research method, which is a research using based on the approach of legal materials, both primary and secondary law. The study results show that the Board of Directors as a corporate organ is responsible for the interests of the Company, if in a Company does not have a Board of Directors, the Company will not be able to operate or operate properly as a legal entity. Then in this case when the term of office of the Board of Directors has expired resulting in a vacancy in the management of the Board of Directors, in the Company Law no one regulates when a Company does not have a Board of Directors.
\end{abstract}

Keywords: Limited Liability Companies, Directors, Responsibilities

\section{Pendahuluan}

\subsection{Latar Belakang}

Di Indonesia terdapat banyak jenis bentuk usaha dalam membangun suatu usaha. Menurut para ahli hukum pada umumnya bentuk usaha di dalam kepustakaan hukum dapat dibagi menjadi 2 (dua) golongan ${ }^{1}$, yang termasuk golongan pertama atau badan usaha yang berbadan hukum adalah Perseroan Terbatas (selanjutnya disebut

1 Suryadi, Asep. "Tanggung Jawab Direksi dalam Kepailitan Perseroan Terbatas." Jurnal Wawasan Yuridika 26, no. 1 (2014): 471-485. 
Perseroan), Koperasi dan Yayasan sementara yang termasuk golongan kedua atau badan usaha yang tidak berbadan hukum adalah Perseroan Komanditer (CV), Perusahaan Dagang (PD), dan Persekutuan Perdata. Jika diperhatikan di dalam dunia usaha kebanyakan para pelaku usaha bisnis lebih tertarik untuk mendirikan badan usaha yang berbadan hukum salah satu yang menjadi paling dominan ialah Perseroan Terbatas). ${ }^{2}$

Kehadiran Perseroan terbatas sebagai suatu badan usaha dalam kehidupan seharihari memang tidak dapat diabaikan lagi keberadaannya. ${ }^{3}$ Perseroan Terbatas didirikan guna untuk memperoleh keuntungan dan kekayaan dalam melaksanakan kegiatan yang dilakukan oleh Direksi. ${ }^{4}$ Perseroan Terbatas menurut ketentuan pasal 1 angka 1 Undang-Undang Nomor 40 Tahun 2007 tentang Perseroan Terbatas (untuk selanjutnya disingkat UUPT) Perseroan Terbatas berbentuk badan hukum didirikan berdasarkan perjanjian, yang melakukan kegiatan usaha dengan modal dasar yang terbagi dalam saham dan memenuhi persyaratan yang diterapkan dalam undang-undang.

Perseroan terbatas sebagai suatu organisasi terdiri dari berbagai organ yaitu Rapat Umum Pemegang Saham (RUPS), Direksi dan Dewan Komisaris. RUPS adalah organ yang memiliki wewenang yang tidak dimiliki oleh Direksi ataupun Dewan Komisaris dalam batasan anggaran dasar atau perundang-undangan. Sementara direksi adalah organ yang menjalankan kepengurusan Perseroan dan Dewan Komisaris adalah organ yang mengawasi Perseron secara umum atau khusus. Direksi dan Dewan Komisaris diangkat oleh RUPS untuk jangka waktu tertentu dan dapat diangkat kembali. ${ }^{5}$

Pada prakteknya tidak jarang ditemui beberapa Perseroan yang telah lewat masa kepengurusan Direksi dan Dewan Komisarisnya namun belum dilakukan RUPS untuk pengangkatan kembali, sehingga secara hukum Direksi dan Dewan Komisaris sebelumnya sudah tidak lagi berstatus sebagai perseroan yang bersangkutan. Padahal suatu perseroan yang tidak memiliki pengurus (Direksi dan Dewan Komisaris) yang sah sama saja seperti badan yang tidak memiliki kaki sehingga tidak akan bisa berjalan. Direksi sebagai organ yang bertugas untuk menjalankan pengurusan, sebagaimana disebutkan pada Pasal 92 ayat (1) UUPT memiliki peranan yang sangat penting, karena Direksi lah yang bertugas untuk menjalankan operasional suatu perseroan. Artinya, suatu perseroan tanpa Direksi sama saja perseroan tersebut tidak bisa menjalankan operasional usaha. ${ }^{6}$

Salah satu contoh perseroan yang sudah habis masa kepengurusan pengurusnya (Direksi dan Dewan Komisaris) namun belum melakukan RUPS untuk pengangkatan kembali adalah PT Artha Komoditi \& Energi Service (PT AKES) sebagaimana bisa dilihat di dalam Penetapan Pengadilan Negeri Jakarta Pusat Nomor

2 Dharmawan, Ni Ketut Supasti. "Keberadaan Pemegang Saham Dalam Rups Dengan Sistem Teleconference Terkait Jaringan Bermasalah Dalam Perspektif Cyber Law." Jurnal Magister Hukum Udayana 4, no. 1 (2015): 44188.

3 Dr. Binoto Nadapdap, Hukum Perseroan Terbatas, (Jakarta, Permata Aksara, 2018), 1.

4 Wulandewi, Ida Ayu Kade Trisna, and I. Nyoman Mudana. "Kedudukan Hukum Perseroan Terbatas yang Anggaran Dasarnya Tidak Sesuai dengan Undang-Undang No. 40 Tahun 2007 Tentang Perseroan Terbatase." Kertha Negara: Journal Ilmu Hukum 7 (2019): 1-20.

5 Gunatri, Desak Nyoman Alit, and Ida Ayu Sukihana. "AKIBAT HUKUM PENGATURAN ACQUIT ET DE CHARGE TERHADAP DIREKSI PERSEROAN." Kertha Semaya: Journal Ilmu Hukum Vol.7 No.3 (2019), 1-15.

6: Triantini, Ni Nyoman Disna, and I. Gusti Ngurah Dharma Laksana. "TANGGUNG JAWAB DEWAN KOMISARIS TERKAIT KEPAILITAN PERSEROAN TERBATAS." Kertha Semaya: Journal Ilmu Hukum Vol.8 No.6 (2020), 954-966. 
176/Pdt.P/2015/PN.Jkt.Pst tanggal 25 Februari 2016 Jo Putusan Mahkamah Konsititusi Nomor 63/PUU-XVI/2018 yang pada pokoknya permohonan pembumbaran pada PT AKES ditolak karena PT AKES tidak memiliki Direksi untuk memberitahukan PT AKES sudah tidak melakukan kegiatan usaha selama (tiga) tahun atau lebih.

Beberapa alasan susahnya melakukan RUPS termasuk RUPS untuk pengangkatan Direksi adalah karena komposisi kepemilikan saham suatu PT masing-masing sebesar $50 \%$ (lima puluh persen) antar pemegang sahamnya atau setidak-tidaknya kepemilikan saham Perseroan tersebut cukup berimbang sehingga terjadi kesulitan untuk mengambil keputusan di dalam RUPS.

Berdasarkan pengamatan yang dilakukan penulis dalam mengkaji karya tulis ilmiah ini murni ditulis dari ide maupun hasil pemikiran penulis. Sepengetahuan penulis belum ditemukan tulisan dengan judul yang sama atau permasalahan yang sama. Namun, ditemukan beberapa karya ilmiah yang mempunyai kemiripan dengan permasalahan yang berbeda. Adapun karya ilmiah yang dimaksud, yaitu karya ilmiah dengan judul "Pertanggungjawaban Direktur Atas Kewenangan Yang Telah Habis Masa Kepengurusannya" yang ditulis oleh Eduard Rudy Suharto, penelitian ini memiliki keterkaitan dalam hal kepengurusan Perseroan Terbatas yang telah habis masa kepengurusannya. Perbedannya terdapat dalam rumusan masalah. Berdasarkan tulisan tersebut memiliki hasil analisis serta tujuan yang berbeda. Sehingga menarik untuk dibahas lebih dalam pada studi ini dengan judul "Perluasan Pengaturan Pengurusan Perseroan Terbatas di dalam Pembaharuan hukum Perseroan Terbatas".

\subsection{Rumusan Masalah}

Berdasarkan latar belakang yang sudah dijelaskan, menarik untuk dikaji permasalahan sebagai berikut :

1. Bagaimanakah Pengaturan Pengurusan Perseroan Terbatas menurut Undang-Undang Nomor 40 Tahun 2007 tentang Perseroan Terbatas?

2. Bagaimanakah Pengaturan Pengurusan Perseroan Terbatas Yang Ideal Dimasa Yang Akan Datang Ketika Terjadi Kekosongan Pengurusan Dalam Perseroan Terbatas?

\subsection{Tujuan Penulisan}

Tujuan penulisan jurnal ilmiah ini agar para pembaca dapat mengetahui perluasan pengaturan pengurusan Perseroan Terbatas di dalam pembaharuan hukum Perseroan Terbatas.

\section{Metode Penelitian}

Bentuk penelitian yang akan dipergunakan dalam penulisan karya ilmiah ini yaitu metode penelitian hukum normatif. Penelitian yang meletakkan hukum sebagai suatu bangunan sistem. Sistem norma yang dimaksud mengenai norma, asas, kaidah dalam peraturan perundang-undangan, aturan hukum, perjanjian serta doktrin (ajaran). ${ }^{7}$. Teknik pengumpulan data menggunakan bahan hukum primer bersumber dari peraturan perundang-undangan dan bahan hukum sekunder meliputi buku-buku dan

7 Diantha, I. Made Pasek, Metodologi penelitian hukum normatif dalam justifikasi teori hukum. (Jakarta Prenada Media, 2016), 8. 
jurnal ${ }^{8}$. Pendekatan ini menggunakan pendekatan konseptual (conceptual approach) dengan menganalisa peraturan perundang-undangan serta catatan hukum, sehingga menemukan ide-ide yang menghasilkan pengertian hukum, konsep hukum dan asasasas hukum dengan isu yang dihadapi. ${ }^{9}$ Teknik data penelitian ilmiah ini bersumber dari studi dokumen dan studi kepustakaan, data yang digunakan untuk menganalisis menggunakan analisis kualitatif.

\section{Hasil dan Pembahasan}

\subsection{Pengaturan Pengurusan Perseroan Terbatas menurut Undang-Undang Nomor} 40 Tahun 2007 tentang Perseroan Terbatas

Direksi adalah bagian dari Perseroan yang berwenang dan bertanggung jawab untuk mengoperasikan suatu perusahaan. Oleh karena itu, menurut UUPT tidak ada organ lain dari Perseroan yang mempunyai kewenangan dan tanggung jawab penuh atas Perseroan selain Direksi. ${ }^{10}$ Direksi sebagai Perseroan yang menjalankan operasional Perseroan terdiri dari beberapa orang, dengan ketentuan apabila terdapat lebih dari satu Direksi maka salah satu diantaranya berposisi sebagai Direktur Utama. Mengenai jumlah anggota Direksi terdiri atas 1 (satu) orang atau lebih, yang berwenang untuk mewakili Perseroan adalah setiap anggota Direksi. Makna kata dari "setiap" yaitu satu persatu orang anggota yang dapat mewakili Perseroan, sehingga pada prakteknya ada berbagai macam jabatan seperti Direktur keuangan dan Direktur pemasaran, oleh karena itu setiap Direksi melakukan tindakan pengurusan sesuai dengan tugasnya.

Menurut ketentuan UUPT, anggota Direksi diangkat oleh RUPS untuk jangka waktu tertentu dan dapat diangkat kembali. Yang dimaksud jangka waktu tertentu adalah Direksi yang masa jabatannya telah habis tidak dengan sendirinya meneruskan jabatannya, kecuali diangkat kembali melalui RUPS. Misalnya dalam jangka waktu 3 (tiga) tahun atau 5 (lima) tahun sejak tanggal pengangkatan, maka sejak berakhirnya masa jabatan Direksi tidak berhak lagi bertindak atas nama Perseroan.

Direksi diangkat melalui RUPS dengan amanat untuk menjalankan, mengurus dan memajukan perseroan memiliki tugas, fungsi, kewenangan yang ditentukan dalam anggaran dasar serta di dalam peraturan perundang-undangan yang terkait dengan hukum Perseroan. Kewenangan yang dimiliki Direksi tidak bersyarat dan tidak terbatas, selama tidak bertentangan dengan anggaran dasar Perseroan dan peraturan perundangundangan.

Sebagaimana telah disebutkan di atas, berikut adalah kewenangan, tugas dan tanggung jawab Direksi dalam melakukan pengurusan terhadap Perseroan:

1) Kewenangan Direksi

Direksi diberikan kewenangan penuh atas nama pengurusan Perseroan untuk melakukan perbuatan hukum dalam mewakili Perseroan di dalam dan diluar pengadilan sesuai dengan Anggaran Dasar. Di dalam Pasal 99 ayat (1) UUPT menyebutkan bahwa Direksi yang berwenang dalam mewakili Perseroan

8 Permana, S. M. S. D., I. Wayan Wiryawan, and I. Ketut Westra. "Kedudukan Hukum Direksi Terhadap Pengelolaan Perseroan Terbatas Yang Belum Berstatus Badan Hukum." Kertha Semaya: Journal Ilmu Hukum 5, no. 2 (2017): 1-5.

$9 \mathrm{Ibid}, \mathbf{1 5 9}$

10 Sjawie, Hasbullah F. "Tanggung Jawab Direksi Perseroan Terbatas Atas Tindakan Ultra Vires." Jurnal Hukum Prioris 6, no. 1 (2017). 
bukan berarti tidak mempunyai batasan-batasan, namun di dalam situasi tertentu Direksi tidak dapat memiliki wewenang untuk mewakili Perseroan.

\section{2) Tanggung jawab Direksi}

Pasal 1 angka 5 UUPT menyatakan Direksi bertanggung jawab secara keseluruhan atas kepengurusan Perseroan. Tanggung jawab Direksi sepenuhnya diserahkan apabila salah satu anggota Direksi melanggar kewajibannya sebagai pengurus, maka setiap Direksi sama-sama memikul secara tanggung renteng bertanggung jawab terhadap kerugian yang dialami Perseroan. ${ }^{11}$ Penerapan Tanggung jawab tersebut hanya dipikul kepada anggota Direksi yang melanggarnya, tanggung renteng tersebut tidak melibatkan anggota Direksi yang lainnya. ${ }^{12}$ Demi memenuhi kerugian dari perbuatan hukum dengan pihak yang telah dirugikan, maka pelaku yang melakukan perbuatan hukum dapat menggugatnya dengan cara pribadi dan tidak pada Perseroan terbatas dengan demikian perbuatan Direksi dilakukan atas nama Perseroan. ${ }^{13}$ Dengan demikian, Ketentuan pada pasal $1365 \mathrm{KUH}$ Perdata tentang perbuatan melanggar hukum dapat digunakan sebagai opsi mengenai tanggung jawab kepada anggota Direksi yang terbukti merugikan pihak ketiga atau pemegang saham.

\section{3) Tugas Direksi}

Berdasarkan pasal 100 UUPT, Direksi memiliki kewajiban untuk menjalankan dan melaksanakan beberapa tugas selama masa jabatannya, Direksi dalam menjalankan tugasnya juga wajib untuk bertukar pikiran, mencurahkan tenaga dan pengabdiannya secara penuh agar mencapai tujuan Perseroan. Setiap anggota Direksi wajib untuk beritikad baik dalam melakukan tugasnya untuk kepentingan Perseroan. ${ }^{14}$ Yang berhubungan dengan itikad baik adalah setiap orang yang menjalankan tugasnya merupakan suatu kewajiban, sudah tentu ada sanksi apabila tidak dilaksanakan. ${ }^{15}$ Sanksinya yaitu berupa memikul tanggung jawab pribadi setiap anggota Direksi yang melakukan tindakan kerugian yang telah dialami menjadi tanggung jawab Direksi secara pribadi yang tidak melaksanakan kewajibannya. ${ }^{16}$

Berdasarkan uraian sebagaimana telah dijelaskan di atas, yang melakukan pengurusan Perseroan menurut UUPT adalah Direksi dan di dalam melaksanakan pengurusan Perseroan masa jabatan Direksi diatur dalam jangka waktu tertentu, pengaturan jangka waktu tertentu tersebut diatur di dalam anggaran dasar masingmasing perseroan. Dan apabila masa jabatan tersebut telah berakhir terhitung menurut

11 M. Yahya Hararap, Hukum Perseroan Terbatas,(Jakarta, Sinar Grafika, 2011), 384

12 Ibid, 385

13 Sri Devi, Ni Made Lalita, "Kedudukan Hukum Perseroan Terbatas yang belum berstatus Badan Hukum", Kertha Semaya : Journal Ilmu Hukum 7, No 5 (2019).

14 Suharto, Eduard Rudy. "PERTANGGUNGJAWABAN DIREKTUR ATAS KEWENANGAN MEWAKILI PERSEROAN TERBATAS YANG TELAH HABIS MASA KEPENGURUSANNYA." JURNAL RECHTENS 8, no. 1 (2019).

15 Isfardiyana, Siti Hapsah. "Tanggung Jawab Direksi Perseroan Terbatas dalam Pelanggaran Fiduciary Duty." Padjadjaran Journal of Law 2, no. 1 (2015).

16 Wauda, Jetly B. "TUGAS DAN TANGGUNG JAWAB DIREKSI SEBAGAI ORGAN DALAM PERSEROAN TERBATAS MENURUT UNDANG-UNDANG NOMOR 40 TAHUN 2007." LEX PRIVATUM 7, no. 4 (2019). 
waktu jabatannya sejak tanggal pengangkatan, maka Direksi yang telah berakhir masa jabatannya tidak serta merta dapat melanjutkan kepengurusan perseroan kecuali berdasarkan pengangkatan kembali melalui RUPS.

Namun selain sebagaimana disebutkan diatas menurut ketentuan Peraturan Ojk Nomor 33/POJK.04/2014 Pasal 30 ayat (2) dan (3) khusus untuk Perseroan terbuka, dalam situasi tertentu Dewan Komisaris dapat melakukan pengurusan terhadap Perseroan terbuka dengan mekanisme harus diatur terlebih dahulu di dalam anggaran dasar Perseroan atau ditunjuk berdasarkan keputusan RUPS.

\subsection{Pengaturan Pengurusan Perseroan Terbatas Yang Ideal Dimasa Yang Akan Datang Ketika Terjadi Kekosongan Pengurusan Dalam Perseroan Terbatas.}

Keberadaan Direksi di dalam suatu Perseroan sangatlah penting, sebab dalam peranannya tersebut dilekatkan tanggung jawab untuk menata suatu Perseroan. Pertimbangan ini menjadikan Rocky Marbun dkk dalam buku Kamus Hukum Lengkap (hal. 74) berpendapat bahwa Direksi adalah organ yang memiliki tanggung jawab penuh untuk kepentingan Perseroan dalam mencapai visi dan misi di luar maupun di dalam pengadilan yang memacu pada anggaran dasar. ${ }^{17}$

Di balik peranannya yang begitu penting dalam melakukan pengurusan terhadap operasional Perseroan, Direksi sebagai suatu jabatan yang diberikan kepada orangorang yang dipilih berdasarkan keputusan RUPS diberikan batasan waktu. Apabila masa jabatan Direksi yang telah habis masa kepengurusannya, tidak dengan sendirinya meneruskan jabatannya yang semula, sehingga tidak berhak bertindak untuk dan atas nama Perseroan kecuali apabila sudah dilakukan pengangkatan kembali oleh RUPS. Terhadap hal tersebut, terjadi permasalahan ketika masa jabatan Direksi yang terbatas tersebut telah habis masa jabatannya namun belum ada RUPS yang melakukan pengangkatan kembali sehingga terjadi kekosongan kepengurusan di suatu Perseroan. Dalam masa-masa kekosongan ini, akan terjadi kebingungan siapa yang akan berwenang mengurus dan menjalankan operasional Perseroan.

Terhadap hal tersebut, Pasal 107 UUPT hanya menentukan bahwa di dalam Anggaran Dasar Perseroan hanya ketentuan pihak yang berwenang menjalankan pengurusan Perseroan dalam hal seluruh anggota Direksi berhalangan atau diberhentikan untuk sementara. Tidak ada aturan yang mengatur siapakah pihak yang berwenang untuk minimal mengurus Perseroan untuk sementara waktu apabila terjadi kekosongan pengurus. Sehingga akan terjadi kebingungan di lapangan manakala situasi kekosongan kepengurusan di dalam suatu Perseroan tersebut terjadi.

Kekosongan pengurus tersebut akan memberikan dampak negatif bagi Perseroan sehingga akan berpotensi terjadinya pemberhentian Perseroan dan terganggunya operasional Perseroan karena tidak memiliki Direksi yang mengurusnya ${ }^{18}$. Sehingga Direksi sebagai suatu organ Perseroan yang memiliki kewenangan menjalankan operasional Perseroan tidaklah boleh lowong walau hanya satu hari saja, karena akan mengakibatkan macetnya operasional suatu Perseroan.

Salah satu contoh kasus Perseroan yang masa jabatan Direksinya telah habis namun belum dilakukan pengangkatan kembali melalui RUPS dapat di lihat di dalam putusan perkara Nomor 825/Pdt.P/2019/PN.Jkt.Brt tentang permohonan

17 Marbun, Rocky, Deni Bram, and A. Nusya Isnaeni Yuliasara. "Kamus Hukum Lengkap." (Jakarta, Visismedia, 2012), 74.

18 Adiningsih, Ni Komang Nea, and M. Marwanto. "Tanggungjawab Organ Perseroan Terbatas (PT) Dalam Hal Kepailitan." Kertha Semaya: Jurnal Ilmu Hukum 7, no. 6 (2019): 1-16. 
menyelenggarakan sendiri RUPS PT Antar Jasa Pratama Agung (PT. AJPA). Di dalam perkara tersebut, sejak berakhirnya masa jabatan Direksi dan Dewan Komisaris PT. AJPA, Perseroan tidak pernah menyelenggarakan RUPS untuk melakukan pergantian atau pengangkatan kepengurusan Perseroan yang baru sehingga Perseroan tidak mempunyai pengurus (Direksi dan Dewan Komisaris). Kekosongan ini membawa dampak negatif bagi Perseroan dan terganggunya operasional Perseroan, sehingga pemegang saham PT. AJPA mengajukan Permohonan menyelenggarakan sendiri RUPS ke Pengadilan Negeri Jakarta Barat sesuai dengan ketentuan UUPT. Hal tersebut dilakukan karena kekosongan kepengurusan PT. AJPA tersebut mengakibatkan kerugian bagi Perseroan dan dampaknya juga akan merugikan pemegang saham dan pihak ketiga.

Akibat dari kosongnya kepengurusan PT. AJPA tersebut, membuat tidak ada Direksi yang bisa melakukan pemanggilan RUPS untuk pengangkatan Direksi yang baru. Hal tersebut kemudian menjadi dasar pemegang saham mengambil insiatif untuk mengupayakan mengajukan permohonan untuk menyelenggarakan RUPS sendiri ke pengadilan, namun tetap saja di dalam masa-masa transisi permohonan tersebut tidak ada yang dapat menjalankan operasional Perseroan. Apalagi permohonan menyelenggarakan RUPS ke pengadilan akan membutuhkan waktu yang cukup lama sehingga pada saat permohonan diajukan tetap saja Perseroan memerlukan pihak yang mengurus operasional sampai adanya RUPS pengangkatan Direksi yang baru.

Contoh kasus tersebut telah menunjukkan bahwa tidak adanya aturan yang mengatur siapa pihak yang berwenang untuk mengurus suatu Perseroan manakala terjadi kekosongan kepengurusan sampai ditunjuknya pengurus yang baru akan mengakibatkan kerugian bagi Perseroan itu sendiri. Bahkan apabila di lihat secara lebih luas, tidak hanya Perseroan sebagai badan hukum saja yang akan dirugikan, namun para pemegang saham dan juga pihak ketiga yang menjalin hubungan dengan Perseroan tersebut.

Sebagaimana mengacu pada penjelasan 3.1 bahwa Dewan Komisaris dapat melakukan tindakan pengurusan perusahaan publik, namun di dalam UUPT yang mengatur Perseroan hanyalah Direksi dan yang menjalankan pengurusan Perseroan dan Dewan Komisaris dalam hal tertentu untuk sesuai dengan ketentuan pasal 30 ayat (2) dan (3) belum ada yang mengatur mengenai siapa yang berwenang untuk menjalankan pengurusan Perseroan manakala Direksi dan Dewan komisaris telah habis masa jabatannya. Hal ini perlu diatur demi kepentingan Perseroan sebagai badan hukum dan pemegang saham.

Berdasarkan hal-hal yang telah diuraikan di atas tersebut, maka dipandang sangat perlu dilakukan perluasan pengurusan Perseroan dalam pembaharuan hukum Perseroan Terbatas (UUPT), perluasan yang dimaksud di sini mencakup 2 (dua) poin penting yaitu, yang pertama adalah ketika terjadi kekosongan kepengurusan Perseroan, UUPT perlu mengatur secara spesifik siapa pihak yang berhak untuk melakukan tindakan pengurusan kepada Perseroan, apakah karyawan, pemegang saham atau Direksi lama sampai adanya Direksi baru. Dan yang kedua adalah, di dalam pembaharuan UUPT perlu mewajibkan setiap anggaran dasar Perseroan untuk mengatur pasal-pasal mengenai siapa yang akan berwenang mengurus Perseroan termasuk untuk mewakili Perseroan di dalam dan di luar pengadilan apabila terdapat permasalahan-permasalahan hukum yang di alami Perseroan. Termasuk aturan mengenai akibat-akibat hukum apabila syarat pengaturan tersebut belum dipenuhi oleh Perseroan di dalam anggaran dasarnya. 


\section{Kesimpulan}

Menurut ketentuan UUPT, Direksi merupakan organ Perseroan yang berwenang dan bertanggung jawab dalam menjalan pengurusan Perseroan, tidak ada organ lain dari Perseroan yang mempunyai kewenangan dan tanggung jawab penuh atas Perseroan. Selain itu, di dalam pembaharuan hukum Perseroan Terbatas sangat perlu dilakukan perluasan pengaturan pengurusan ketika mengalami kekosongan kepengurusan diantaranya adalah tentang siapa pihak yang berhak untuk melakukan pengurusan Perseroan, apakah karyawan, pemegang saham atau Direksi lama sampai adanya Direksi baru serta di dalam pembaharuan UUPT perlu mewajibkan setiap anggaran dasar Perseroan untuk mengatur pasal-pasal mengenai siapa yang akan berwenang mengurus Perseroan termasuk aturan mengenai akibat-akibat hukum apabila syarat pengaturan tersebut belum dipenuhi oleh Perseroan di dalam anggaran dasarnya. Sebaiknya di dalam pembaharuan UUPT perlu dilakukan perluasan terhadap pengaturan pengurusan Perseroan Terbatas sehingga dapat menghindari kerugian yang dialami oleh Perseroan sebagai badan hukum.

\section{DAFTAR PUSTAKA}

\section{Buku}

Dr. Binoto Nadapdap, Hukum Perseroan Terbatas, (Jakarta, Permata Aksara, 2018).

I Made Pasek Diantha, Metodologi Penelitian Hukum Normatif dalam Justifikasi Teori Hukum, (Jakarta,Prenada Media Grup,2016).

M. Yahya Hararap, Hukum Perseroan Terbatas, (Jakarta, Sinar Grafika, 2011).

Marbun, Rocky, Deni Bram, and A. Nusya Isnaeni Yuliasara. Kamus Hukum Lengkap, (Jakarta, Visimedia, 2012).

\section{Jurnal}

Adiningsih, Ni Komang Nea, and M. Marwanto. Kertha Semaya: Journal Ilmu Hukum 7, no. 6 (2019).

Dharmawan, Ni Ketut Supasti. "Keberadaan Pemegang Saham Dalam Rups Dengan Sistem Teleconference Terkait Jaringan Bermasalah Dalam Perspektif Cyber Law." Jurnal Magister Hukum Udayana 4, no. 1 (2015): 44188.

Gunatri, Desak Nyoman Alit, and Ida Ayu Sukihana. "AKIBAT HUKUM PENGATURAN ACQUIT ET DE CHARGE TERHADAP DIREKSI PERSEROAN." Kertha Semaya: Journal Ilmu Hukum Vol.7 No.3 (2019), 1-15.

Isfardiyana, Siti Hapsah. "Tanggung Jawab Direksi Perseroan Terbatas dalam Pelanggaran Fiduciary Duty." Padjadjaran Journal of Law 2, no. 1 (2015).

Permana, S. M. S. D., I. Wayan Wiryawan, and I. Ketut Westra. "Kedudukan Hukum Direksi Terhadap Pengelolaan Perseroan Terbatas Yang Belum Berstatus Badan Hukum." Kertha Semaya: Journal Ilmu Hukum 5, no. 2 (2017): 1-5.

Suryadi, Asep. "Tanggung Jawab Direksi dalam Kepailitan Perseroan Terbatas." Jurnal Wawasan Yuridika 26, no. 1 (2014): 471-485.

Sri Devi, Ni Made Lalita, "Kedudukan Hukum Perseroan Terbatas yang belum berstatus Badan Hukum", Kertha Semaya : Journal Ilmu Hukum 7, No 5 (2019).

Suharto, Eduard Rudy. "Pertanggungjawaban Direktur Atas Kewenangan Mewakili Perseroan Terbatas yang Telah Habis Masa Kepengurusannya." JURNAL RECHTENS 8, no. 1 (2019)

Sja wie, Hasbullah F. "Tanggung Jawab Direksi Perseroan Terbatas Atas Tindakan Ultra Vires." Jurnal Hukum Prioris 6, no. 1 (2017). 
Triantini, Ni Nyoman Disna, and I. Gusti Ngurah Dharma Laksana. "TANGGUNG JAWAB DEWAN KOMISARIS TERKAIT KEPAILITAN PERSEROAN TERBATAS." Kertha Semaya: Journal Ilmu Hukum Vol.8 No.6 (2020), 954-966.

Wauda, Jetly B. "Tugas dan Tanggung Jawab Direksi Sebagai Organ Dalam Perseroan Terbatas Menurut Undang-Undang Nomor 40 Tahun 2007." LEX PRIVATUM 7, no. 4 (2019).

Wulandewi, Ida Ayu Kade Trisna, and I. Nyoman Mudana. "Kedudukan Hukum Perseroan Terbatas yang Anggaran Dasarnya Tidak Sesuai dengan UndangUndang No. 40 Tahun 2007 Tentang Perseroan Terbatase." Kertha Negara: Journal Ilmu Hukum 7 (2019).

\section{Peraturan Perundang-undangan}

Undang-Undang Nomor 40 Tahun 2007 tentang Perseroan Terbatas, Lembaran Negara Tahun 2007 No.106, Tambahan lembaran Negara Tahun 2007, No. 4756.

Kitab Undang-Undang Hukum Perdata Buergerlijke Wetboek, 2004, diterjemahkan oleh R. Subekti dan R. Tjitrosudibio, Pradnya Paramitha, Jakarta.

Peraturan Otoritas Jasa Keuangan Nomor 33/POJK.04/2014 Tentang Direksi dan Dewan Komisaris Emiten Atau Perusahaan Publik. 